\title{
IAMJ
}

INTERNATIONAL

AYURVEDIC

MEDICAL JOURNAL

\section{NON-PHARMACOLOGICAL MANAGEMENT OF COVID19 PATIENT}

\author{
Swati Thakre', Mangesh Nalkande ${ }^{2}$
}

${ }^{1}$ Swati Ambadas Thakare, Associate Professor, Dept of Panchakarma, Dr R N Lahoti Ayurved Medical College, Hospital and Research Centre, Sultanpur Dist Buldhana (Maharashtra), India

${ }^{2}$ Mangesh Wasudeo Nalkande, Assistant Professor, Dept of Kayachikitsa, Govt Ayurved College Nanded, (Maharashtra), India

Corresponding Author: drawathiayurveda@gmail.com

https://doi.org/10.46607/iamj5709092021

(Published Online: September 2021)

Open Access

(C) International Ayurvedic Medical Journal, India 2021

Article Received: 30/08//2021 - Peer Reviewed: 06/09/2021 - Accepted for Publication: 07/09/2021

\section{Check for updates}

\section{INTRODUCTION}

Now the whole world is under the influence of COVID 19 infection. COVID-19 is caused by a specific Coronavirus (SARS-CoV2). A Coronavirus primarily causes enzootic infections in animals but can transfer to humans and cause infections. Many countries are focusing on vaccination along with the proper isolation guidelines, and others are adopting the Alternative methods to be found to control the overspread of the virus.

Coronaviruses typically cause symptoms that are like influenza (The Flu) and other viral illnesses. The most common symptoms of COVID-19 are fever greater than 100.4 degrees F, tiredness, body aches, dry cough, shortness of breath, headache, body ache, chills, Loss of taste or smell.

The majority of patients has mild or moderate symptoms and don't require hospitalization. With these milder symptoms, you should stay home, rest and avoid contact with others so you don't spread the virus. Drink plenty of fluids and take a Proper diet as needed. ${ }^{1}$

Sometimes patients - usually those who are elderly or with underlying health issues - may develop moderate symptoms that could require some supportive care, such as a healthy diet, fluids for dehydration.

Another red flag is shortness of breath, particularly if you're not engaging in any activity. Any shortness of 
breath combined with these other symptoms should be checked out.

Generally, a mild to moderate case of COVID-19 will run its course in about two weeks, according to a World Health Organization (WHO) report. These days, if the patient took proper care of diet and nutrition it will provide better results.

\section{Importance of proper diet in Covid 19}

We all might hear about the famous quote of Greek physician Hippocrates, "Let food be thy medicine, and let medicine be thy food". This sentence explains that "When diet is wrong, medicine is of no use; when the diet is correct, medicine is of no need."

Ayurveda is an ancient science that provides solutions to any disease in a multidisciplinary way by personalized herbal drugs, exercise and yoga for maintaining body and mind harmony, and most important is individual diet regiment as per body strength and disease. Every chapter of the Ayurveda book ends with suggestions and contraindications for diet. Even after the detoxification of body gut strength diminished to support the gastrointestinal tract light diet, rich in nutrient recipes are recommended.

In the chapter of Charak Samhita, i.e., Jwara chikitsa, Kasa chikitsa most of the complaints found in Covid infection are as similar as mentioned in the text, and more emphases on correction of dehydration and weakness. Broadly, all formulations come under the concept of Pathya Kalpana.

Forthcoming paragraphs explain the principles to enhance the efficacy of management of this outbreak also to make body rich in nutrient 'Diet regimen' should be followed that fulfil all deficiency.

After infection of Covid19 digestive fire would get weak due to excessive elimination of doshas. In such conditions, if a patient consumes excessive food, it will badly impact the digestive system and its functional entity i.e., the digestive fire. Weakened fire will not be capable of digesting food properly and hence indigestion may set in, which were commonly nowadays. Undigested food may consequentially cause many complications. Hence normal food should not be given after covid 19 treatments. To strengthen digestive fire and to make it capable enough of digesting all forms of food, the diet is gradually graduated from liquid to solid foods until the patient is allowed to consume regular foods compatible with him at end of the regimen.

\section{Non-dietary regimen}

- Therapeutic Ayurvedic Fasting / लंघन ${ }^{2}$

Covid symptoms are started with pyrexia, consequently, the patient complains about tastelessness, dryness of mouth, weakness. Instead of taking heavy meals if the patient follows a light diet than routine diet i.e., Ayurveda fasting. Langhan is one of the six basic principles explained by Ayurveda called Shataupakrama. Langhan means the food which gives lightness to the body. If food will not be available for digestion, then the gastric acid (Agni) will metabolize the unsaturated food material (Aama dosha) result in enhanced digestion (Agnidipan) and Aama pachan.

\section{- Room Temp. उष्णगृह}

Low temperature provides a susceptible environment to grow bacteria and accumulate Kaph dosha in the body. Avoidance of direct cold exposure or maintaining room temperature more than $24 \mathrm{c}$ helps for mucolysis and removal of productive secretion from lungs. So, it is better to stay in a fresh air room with proper ventilation.

\section{-Medicated Decoction/Warm Water to Drink/ सिद्धजल / क्रथित जल / उष्णोदक पान ${ }^{3}$}

The water which is reduced to $1 / 8$ th part or $1 / 2$ part or simply by boiled water is known as Ushnodaka. They are laghu (light), Accha (clear) and sudha (neat). They can reduce Kapha (Mucus), Vayu (vitiated Vata dosha) and Meda (Adipose tissue). They are Deepana (Appetizer) and Vastishodhana (cleansing urinary bladder). They can be administered in Parsvasoola (Backache), Pinasa (Rhinitis), Adhmana (Inflatulence), Hikka (Hiccup), Trushna (Thirst), Svasa (Dyspnea), Sula (Painful condition), etc: conditions.

\section{-Deep Breathing Exercise /दीर्घश्वसन}

Respiratory exercises like Pranayam, Anuloma, viloma and Bhramari may help in mild cases to improve the vital capacity of the lungs. Also practising on devices like spirometer will show the status of lungs health. Some research stated that Bhramari is helpful by enhancing the expression of Nitric Oxide and 
increased Carbon dioxide by extended exhalation and alkaline $\mathrm{pH}$ prevents coagulopathies and morbidity due to Covid-19.

Regular Deep breathing exercises must be done to improve oxygen consumption. ${ }^{4}$

\section{-Ayu. Gargling /गण्डूष ${ }^{5}$}

Proper care of the mouth should be taken while the incidence of Covid19. The oral cavity is continuously flushing saliva and facilitates the flow of the food debris to keep clean the mouth. Salivary secretions are comparably slow down during sleep; that's why the bacterial growth increases in the mouth resulted in the foul smell of breath in the morning. Salivary enzymes are carried out lyses of so many bacteria that prevent the microbial population's excessive growth in the oral cavity. Because of this phenomenon, researchers suggested salivary fluid analysis to predict or to diagnose or to avoid health-related issues and overcome future unwanted illnesses. The variety of molecules freely travels through the cells and can have assessed in the salivary ducts, which can be analyzed in the assay of salivary fluid. These small molecules are hormones, a chemical indicator of health, various types of enzymes, toxins. It is hypothesized that the tongue, a sense organ, relates to vital organs like the lungs, heart, intestine, kidney. Oil/Decoction pulling helps to excrete toxic metals through saliva, where salivary enzymes absorb blood toxins like chemicals, bacterial, and environmental and expelled through the tongue. It is a simple mechanism that works in oleation therapy. Oil/Decoction pulling is a form of retention of fluid in the mouth for a specibic period till the occurrence of lacrimation and nasal discharge. After that, the patient is advised to spit out. Regular use of oil pulling facilitates strength to voice, jaws, face and better taste perception, strong and healthy teeth, and protects the oral cavity from other diseases. The medicated liquid or oil's active ingredients and chemical constituents stimulate the chemoreceptors and mechanoreceptors and produce the salivary nuclei in the brain stem. As a result, the parasympathetic nervous system activates and increases impulses through motor fibres in facial and glossopharyngeal nerves. All the process forcefully increases the output of salivary secretion, which is predominantly watery. That helps to dislodge the metabolic toxins, food debris, depositions, and microorganisms present in the oral cavity, mixed with retained medicated liquid or oil, and removed from the oral cavity

\section{Dietary regimen}

The patient suffered from corona infection majorly shows the symptoms of fever results in weakness, body ache. In this situation to boost the strength of the patient diet should give as per their basal metabolic rate and be rich in nutrition by avoiding a high-fat diet. Patient unable to digest solid food, so gradual intake of liquid to a semiliquid and finally solid meal should be done. In Ayurveda, it is named Pathya Kalpana. Pathya Kalpana is a basic but most importantconcept in Ayurveda that seems to be practical and must be practised clinically in today's era.

The preparations made by(Samskara) various methods of processing make the diet - more fruitful in terms of health. The importance of understanding "Pathya Kalpana" can be seen from the following points -

$>$ These preparations are made up from minimum \& easily available ingredients

$>$ These are Simple methods of preparation.

$>$ These are very Cost-effective methods.

The concept of Pathya changes at every momentand with every individual. What is Pathya toone person may not be Pathya to anotherperson. Even if changes in the same persondepending upon various components like -Age-psychological condition- the condition of provocative Dosha-condition of Dhatuscondition of raw material- area of the patienthabits of the patient etc.

So, considering and elaborating the diet plan need a lot ofattention from the physician.

Practically Pathya Kalpana is advised as a diet plan 'in healthy individuals' to let them stay fit, 'to the patients' to keep their channels in a healthy stage and in 'patients get- ting treated with Panchakarma' to help theirGastro-intestinal tract coming back to normal.

\section{Manda Kalpana- ${ }^{6}$}

This Kalpana is prepared by using rice and water in $1: 14$ proportion. The rice is cooked in the said proportion of water and then only the water content of the 
prepared formulation is collected as Manda (a watery portion of rice gruel).

Biological properties: Laghu (light in digestion), Sheeta (cold)

Biological actions: Deepana (increase in appetite), Pachana (increase in digestivecapacity), Grahi (reduces water content in faeces), $V$ a t a n u lo m a ka (maintains normal functioning of Vata humour), Kaphaghna (pacify Kapha humour).

Indications: Jwara (Fever), Atisara (Diarrhea), Trishna (Excess Thirst).

Indicated conditions: After Vamana/Virechana, after exertion, after fasting.

Peya Kalpna: ${ }^{7}$

This Kalpana is prepared by using rice and water in 1:14 proportion. The rice is cooked in the said proportion of water and then the maximum watery content of the prepared formulation is collected with a few grains of cookedrice is known as Peya (rice gruel).

Biological properties: Laghu

Biological actions: Deepana, Pachana, Vatanulomaka, Dhatupushtikara (nourishes basic body elements)

Peya was prescribed in the treatment different clinical conditions with different ingredients as follows.

\section{Vilepi $^{8}$ (Thick Rice Gruel):}

This is a thick rice gruel prepared by cookingrice with 4 times of water.

Biological properties: Madhur (sweet),
Laghu (light indigestion).

Biological action: Deepana, Rochaka (Enhances taste), Grahi, Vrushya (enhance the strength).

\section{Yavagu (Rice Gruel):}

Rice, the main ingredient in yavagu is rich in carbohydrates and its easily digestive property with high nutritive value; make it the appropriate food article for patients as well as healthy persons, who have mandagni (low digestive capacity). It also works as the media for various drugs by utilizing drug decoctions in place of water and drug power as adjuvant.

Yavagu is a type of gruel prepared with 6 times water to nearly thick or semisolid consistency. Yavagu may be prescribed as antipyretic, antidysentric, anticolic, antihelminthic and antitoxic

Yusha ${ }^{9}$

Jal, Kwatha, Swarasa, Hima and Takra etc. Drava Dravya is mixed with Simbi Dhanya except for rice and cooked well. The obtained liquid portion is called Yusha Kalpana. For the preparation of Yush Mridu Virya Dravya Kalka is taken 1 Pal and Shunthi, Pippali etc. Tikshna Virya Dravya is supposed to be taken in 1 Karsha and mixed with 1 Prastha of water and boiled up to contents are reduced to $1 / 2$ of the quantity or according to the need after those contents are filtered with cloth and obtained liquid is called Yusha. According to Acharya Sharangdhara Yusha also can be prepared with one part of Dravya and fourteen parts of water, the same proportion used in Peya, but Yusha is prepared in thick consistency.

\section{Nutritional facts per $10 \mathrm{gm}$ premix*}

\begin{tabular}{|r|l|l|}
\hline Sr.no. & Nutrition & Quantity \\
\hline 1. & Calories & $36.8 \mathrm{kcal}$ \\
\hline 2. & Carbohydrates & $6.4 \mathrm{~g}$ \\
\hline 3. & Protein & $2.8 \mathrm{~g}$ \\
\hline 4. & Fats & 0 \\
\hline 5. & Dietary fibres & $0.45 \mathrm{~g}$ \\
\hline
\end{tabular}

*Approximate

\section{Hydration}

The maintenance of hydration is essential for overall health. How much water we need depends on our age, sex, weight, height, level of physical activity and environmental conditions (i.e., hot weather will likely require you to drink more water). Considering that around 20-30\% of the water we need comes from our food, the European Food Safety Authority has set 
average recommendations for how much water we should drink per day depending on our age. Mild dehydration (fluid loss of 1-3\%) can impair energy levels, impair mood, and lead to major reductions in memory and brain performance. ${ }^{10}$

If you have access to safe tap water, this is the healthiest and cheapest drink. For a refreshing boost, you can add slices of lemon, cucumber, mint, or berries. Other drinks such as unsweetened coffee and tea or iced tea, or unsweetened, infused or flavoured (sparkling) water are also good choices for hydration.

\section{CONCLUSION}

In a nutshell, everyone tries their best to get rid of this trouble. Many countries even started vaccinating, others are focused on inventing new antiviral drugs. In parallel to these efforts, if we took care of the patient by alternative methods, it may be beneficial for not only mild to moderate but post covid infected patients also. Consequently, the Non-Dietary and Dietary regimen mentioned above will not only enhances the nutritional status of patient but also keep them hydrated which will surely improve the situation.

\section{REFERENCES}

1. https://elitelv.com/doctors-corner/asymptomatic-ormild-covid-19/15May21

2. Charakasamhita Sutrasthan 22/34-35

3. Vagbhat sutrasthan ashtang sangraha saroj Hindi commentary reprint edi. Varanasichaukhanba surbh arti prakashan,2001, p97

4. https://www.healthline.com/health/breathing-exercises-for-covid15May21

5. VriddhaVagbhatt: Ashtanga Hrudaya with Commentaries of Sarvangasundara of Arunadatta\& Ayurveda Rasayana of Hemadri edited by Pt. Hari Sadashiva Shastri Paradakara, ChoukambhaSanskrit Samsthana, Varanashi, Re-print (2012); p.25,

6. Acharya Sushrut. Samhita.Ambika Dutt Shastri Editor.Reprint 2010. Sutrastana 46/344-45

7. Sharangdhara. sharangdhara samhita madhyama khanda 3/167-169

8. Acharya Sharangdhara.Sharangdhar Samhita.4th Edition, Chaukhamba Orientalia, 2005, Madhyama Khanda 2/154

9. Agnivesha Charaka Samhita, Vidhyotini Hindi commentary Edited by Kashinath Shastri \& Gorakhnath Chaturvedi, Chaukhamba Bharti Academy, Varanasi, Sutrasthana 27/ 7, 2016, 526.
10. https://www.healthline.com/nutrition/7-health-benefits-of-water\#2.-Significantly-affects-energy-levelsand-brain-function15May21

\section{Source of Support: Nil Conflict of Interest: None Declared}

How to cite this URL: Swati Thakre \& Mangesh Nalkande: Non-Pharmacological Management Of Covid19 Patient. International Ayurvedic Medical Journal \{online\} 2021 \{cited September 2021\} Available from: http://www.iamj.in/posts/images/upload/2285_2289.pdf 